\title{
Physical characteristics of potato flour from 'Ibituaçú' cv. under different extrusion parameters
}

\author{
Características físicas de farinha de batata cv. 'Ibituaçú' \\ submetida a diferentes parâmetros de extrusão
}

\author{
Raema Fortes Vicente Cardoso ${ }^{\mathrm{I}}$ Émerson Loli Garcia ${ }^{\mathrm{I}}$

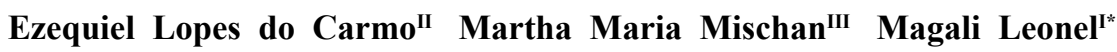

\begin{abstract}
This study aimed to evaluate potato flour from 'Ibituaçu' cultivar as raw material for extrudates. Potato flour was processed in a single-screw extruder following central composite rotational design for three factors, being considered as independent parameters: temperature in the third zone, humidity and screw speed. The products obtained were characterized by expansion index (EI), specific volume (SV), water solubility index (WSI), water absorption index (WAI), hardness $(H)$, color $\left(L^{*}, a^{*}\right.$ and $\left.b^{*}\right)$. Results showed an effect of the independent parameters on the extruded physical characteristics. The parameters varied from: 3.22 to 5.47 (EI); 2.08 to $11.23 \mathrm{~mL} \mathrm{~g}^{-1}(\mathrm{SV}), 32.88$ to $63.72 \%$ (WSI), 4.02 to $8.97 \mathrm{~g}_{\text {gel }} \mathrm{g}^{-1}$ (WAI), 7.54 to $29.85 \mathrm{kgf}(\mathrm{H}), 53.89$ to $68.72\left(L^{*}\right), 5.59$ to $6.92\left(a^{*}\right), 16.6$ to $22.6\left(b^{*}\right)$. It was concluded that expanded products with desired physical characteristics are obtained at high temperature; low humidity and intermediate screw speed.
\end{abstract}

Key words: Solanum tuberosum L., extrusion, physical properties.

RESUMO

Oobjetivo deste trabalho foi avaliar a farinha de batata cultivar 'Ibituaçu' como matéria prima para o desenvolvimento de produtos extrusados. A farinha de batata foi processada em extrusor mono-rosca seguindo delineamento central composto rotacional para três fatores, sendo considerados como variáveis independentes a temperatura na $3^{a}$ zona, a umidade e a rotação da rosca. Os produtos obtidos foram caracterizados quanto ao índice de expansão (IE), volume especifico (VE), índice de solubilidade em água (ISA), indice de absorção de água (IAA), dureza (D) e cor ( $\left.L^{*}, a^{*} e b^{*}\right)$. Os resultados mostraram efeito das variáveis independentes sobre as características fisicas dos produtos. O IE dos produtos variou de 3,22 a 5,47, o VE de 2,08 e 11,23 mL.g $\mathrm{g}^{-1}$ o ISA de 32,88 a 63,72\% o IAA de 4,02 a 8,97 $\mathrm{g}_{\mathrm{gel}} \mathrm{g}^{-1}, \mathrm{D}$ de 7,54 a 29,85kgf, $L^{*}$ de 53,89 a $68,72, a^{*}$ de 5,59 a 6,92, $b *$ de 16,6 a 22,6. Nas condições de elevada temperatura, baixa umidade, e rotação da rosca intermediária são obtidos produtos extrusados com características físicas desejadas para produtos expandidos.

Palavra-chave: Solanum tuberosum L., extrusão, propriedades fisicas.

\section{INTRODUCTION}

In recent years, extrusion technology has been acquiring a high profile and has become one of the main processes for adding commercial value to raw material (LEONEL et al., 2006). By virtue of its operational adaptability and multiple functions, this technology has found a wide range of applications for both animal and human food industry.

Extrusion is a cooking process for a short time at high temperature, in which a combination of mechanical shear action, heat and humidity resulting in a molecular rearrangement besides other chemical reactions, giving the processed product special and diversified characteristics (FERRARI et al., 2014). During extrusion process, a whole series of changes take place in the raw material such as starch and protein hydration, homogenization, starch gelatinization, protein denaturation, destruction of anti-nutritional factors and microbial load reduction (VERNAZA et al., 2009).

Raw material used in extrusion process play an important role in product structure and

\footnotetext{
'Centro de Raízes e Amidos Tropicais (CERAT), Universidade Estadual Paulista “Júlio de Mesquita Filho” (UNESP), Rua José Barbosa de Barros, 1780, 18610-307, Botucatu, SP, Brasil. E-mail: mleonel@cerat.unesp.br. "Corresponding author.

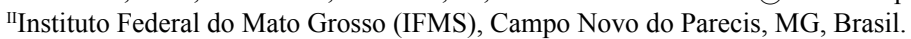

IIIInstituto de Biociências, UNESP, Botucatu, SP, Brasil. 
quality, being humidity, physical state, particle sizes, chemical composition and $\mathrm{pH}$, some of the most important factors to be checked. Different types of raw materials generate fully diversified products even under the same extrusion (FELLOWS, 2006).

Root and tuber-based product development, e.g. potatoes, has aroused interest of the processing industries, and improve the entire production chain by providing better crop use (LEONEL et al., 2006). Potato is characterized as a popular food and the third most important crop for human nutrition, being consumed by more than 1 million people, and cultivated over 125 countries (FAO, 2009). All important potato cultivars in Brazil are foreign and developed at different climatic conditions. As a result, they are not properly adapted to the Brazilian soil and weather conditions, requiring high amounts of inputs to achieve ideal yield, which can put at risk not only competitiveness but also environmental, economic and social sustainability. For these reasons, studies have been required to develop new cultivars with agronomic and culinary qualities superior to those currently offered on market (RAMOS et al., 2009).

Evaluating the performance of potato genotypes for agronomic characteristics and tuber qualities in Southwestern and Northeastern São Paulo State, RAMOS et al. (2009) concluded that the APTA 2.5 and 'Ibituaçú' clones are indicated for both production and feed, given the notable dry matter content, yield and pest resistance.

In Brazil, there are many potato-processing forms still little explored, such as starch production, flakes, flour and a large amount of extrudates such as pre-gelatinized starches, instant flour, snacks, soups, noodles, etc. Aiming to combine the extrusion technology and the importance of developing new markets, and considering the interests of producers and processing industries to introduce products with greater added value using potato cultivars still unexplored; this study aimed to evaluate the effect of extrusion parameters on physical characteristics of extrudates made from potato flour from 'Ibituaçú' cultivar.

\section{MATERIAL AND METHODS}

Flour was obtained by processing potato tubers of the 'Ibituaçú' cultivar (IAC 6090) from ItararéSP, Brazil. Seed potatoes were planted in August 2012. Harvest was manually carried in November 2012, after total drying of crop aerial part. The harvested tubers were washed in tap water and shade dried. Then, tubers with signs of spoilage were removed.

For flour production, $120-\mathrm{kg}$ selected tubers were sliced and immersed into a sodium bisulfite solution $(0.5 \%)$ for 10 minutes. After draining using sieves, the material was dried in forced air oven at $45^{\circ} \mathrm{C}$ for 48 hours. Next, dehydrated slices were ground in a cutting mill (MARCONI - MA 340). Then, produced flour was placed into plastic boxes for further characterization (humidity, protein, lipid content, ashes, total sugars, starch, fibers and $\mathrm{pH}$ ) and extrusion processing

Flour humidity content was measured according to method of the AOAC (2007), in which samples are placed in an oven at $105^{\circ} \mathrm{C}$ up to constant mass and moisture percentage obtained by weight difference. Yet the ash content was determined by subjecting the samples to burning in furnace for 2 hours at $550^{\circ} \mathrm{C}$. Moreover, the protein content was obtained by the Kjeldahl method, as proposed by the AOAC (2007), with a protein conversion factor of 6.25.

Lipid content determination was made using three grams of the sample to perform Soxhlet extraction, using petroleum ether for dragging. Dietary fiber content was obtained by acid hydrolysis followed by alkaline hydrolysis, for which three grams of sample processed in fiber digester block was used (AOAC, 2007).

Total sugar content was determined by Somogy method adapted by Nelson (1944). Five hundred milligram sample was weighed and added by $60 \mathrm{~mL}$ of $50 \% \mathrm{EtOH}$. The sample was placed in a water bath heated at $65^{\circ} \mathrm{C}$ for 60 minutes. After that, it was added $1 \mathrm{~mL} \mathrm{HCl}$, returning to the bath for another 60 minutes, after the samples were cooled, neutralized, diluted and quantified. Starch content was analyzed by means of enzymatic hydrolysis according to the method proposed by RICHARD \& BENH (1987).

The extrusion process was carried out in an IMBRA-RX complete extruder line (Inbramaq $\mathrm{S} / \mathrm{A}$ ) with a single screw and production capacity of $50 \mathrm{~kg} \mathrm{~h}$. . The evaluated parameters were divided into fixed and variable. The fixed ones were compression ratio $(3: 1)$, feeding $\left(150 \mathrm{~g}\right.$. $\left.\mathrm{min}^{-1}\right)$, matrix opening $(3 \mathrm{~mm})$ and temperatures at first $\left(25^{\circ} \mathrm{C}\right)$ and second zone $\left(45^{\circ} \mathrm{C}\right)$. After conducting preliminary tests, it was defined as variable parameters the third zone extrusion temperature (ranging from 83 $117^{\circ} \mathrm{C}$ ), flour humidity (12 to $19.5 \%$ ) and screw speed (from 194 - 247rpm).

The combined effect of independent parameters was assessed by central composite rotational design for three factors according to COCHRAN \& COX (1957), totaling 20 treatments. Wherein: a) Eight treatments corresponded to the $2^{3}$ factorial, with the factors screw speed (SS), temperature $(\mathrm{T})$, moisture $(\mathrm{M})$, each one encoded by 
two levels -1 and +1 ; b) 6 treatments with minimum and maximum levels of each factor, encoded as $-\alpha$ and $+\alpha$, respectively, in which $\alpha=2^{3 / 4}=1.682$, and a central treatment with 6 replications (Table 1).

Deionized water was used to set treatment humidity levels following the formula: $\mathrm{Y}=\left(\mathrm{U}_{\mathrm{f}}-\mathrm{U}_{\mathrm{i}}\right) \times \mathrm{P}$ / $100-U_{f}-$ Wherein: $Y=$ water amount in $\mathrm{mL} ; \mathrm{U}_{\mathrm{f}}=$ intended humidity; $\mathrm{U}_{\mathrm{i}}=$ initial humidity; $\mathrm{P}=$ sample weight $(\mathrm{g})$.

Extrudates were characterized concerning specific volume (SV), expansion index (EI), water absorption index (WAI), water solubility index (WSI), color and texture. Specific volume was determined according to the mass-displacement method using a graded cylinder and volume assessed by the equation: $\mathrm{SV}=\mathrm{v} / \mathrm{p}$, wherein: $\mathrm{SV}=$ specific volume $(\mathrm{mL}$ $\left.\mathrm{g}^{-1}\right), \mathrm{p}=$ mass $(\mathrm{g})$ and $\mathrm{v}=$ volume $(\mathrm{mL})$ (SALATA et al., 2014). Expansion index (EI) was obtained by the arithmetic mean of product diameter by the matrix diameter of 20 different expanded products (FAUBION \& HOSENEY, 1982).

The indexes of water absorption (WAI) and water solubility (WSI) were assessed according to the method described by Anderson et al. (1969). The WAI was calculated according to the following equation: WAI $=\mathrm{CRW} / \mathrm{SW}-\mathrm{ERW}$, wherein: $\mathrm{WAI}=$ water solubility index $\left(\mathrm{g}_{\mathrm{gel}} \mathrm{g}^{-1}\right), \mathrm{CRW}=$ centrifugation residue weight $(\mathrm{g})$, $\mathrm{SW}=$ sample weight $(\mathrm{g})$ and $\mathrm{ERW}=$ evaporation residue weight $(\mathrm{g})$. Yet the WSI was calculated according to the equation: WSI $=\mathrm{ERW} / \mathrm{SW} \times 100$, wherein: WSI = water solubility index $(\%), \mathrm{SW}=$ sample weight $(\mathrm{g})$ and $\mathrm{ERW}=$ evaporation residue weight $(\mathrm{g})$.

For color determination, it was used a Minolta CR-400 colorimeter (Konica Minolta Sensing). The coordinates were $\mathrm{L}^{*}$ (lightness), a* indicating chroma variation from green $(-60)$ to red (60), and $b^{*}$ the variation from blue $(-60)$ to yellow (60) (SPINELLO et al., 2014).

Extrudate texture were measured for 10 samples per treatment using a TA.XT2.Plus texture analyzer (Stable Micro Systems, Surrey, England), with a $50 \mathrm{~kg}$ load cell and a HDP/ WBV probe and a test speed of $1 \mathrm{~mm} / \mathrm{s}$ (TAVERNA et al., 2012).

Table 1 - Variation levels and independent parameters in extrusion process of potato flour from 'Ibituaçú cultivar.

\begin{tabular}{|c|c|c|c|c|c|}
\hline \multirow{2}{*}{ Parameters } & \multicolumn{5}{|c|}{--------------------- Levels } \\
\hline & $-\alpha$ & -1 & 0 & 1 & $+\alpha$ \\
\hline Temperature $\left({ }^{\circ} \mathrm{C}\right)$ & 83 & 90 & 100 & 110 & 117 \\
\hline Moisture (\%) & 12,5 & 14 & 16 & 18 & 19,5 \\
\hline Screw speed (rpm) & 194 & 205 & 220 & 235 & 247 \\
\hline
\end{tabular}

$\alpha=1.682$.
All analyzes were performed in triplicates and the results submitted to statistical analysis using the stepwise option of the SAS software, and further validation by F-test at 5\% significance. Within the construction of the response surfaces, two independent parameters had changes in the studied areas and the third was fixed at the center point.

\section{RESULTS AND DISCUSSION}

Potato 'Ibituaçu' flour showed significant contents of starch $(62.23 \%)$, protein $(8.17 \%)$, fiber (10.61\%), lipids (7.40\%) and ashes (2.69\%), and low of sugar $(0.40 \%)$, being interesting for extruded food products (FELLOWS, 2006). Regression coefficients' analysis showed for extrudates a significant influence of joint and/ or individual interaction of humidity, screw rotation and temperature on the evaluated parameters (Table 2).

Food expansion depends on matrix and atmosphere pressure difference (SPINELLO et al., 2014). The values of EI ranged from 3.22 to 5.47. This parameter had positive linear and quadratic effect of temperature and negative linear effect of humidity as shown by data analysis. Larger ratios were obtained in less moisture content and higher extrusion temperature conditions, as shown in figure 1a. LEONEL et al. (2009) observed similar behavior in extrudates from cassava starch. EI is a quality indicator; the more expanded products tend to be the more crisp they will be, which increases consumer market acceptability (FERRARI et al., 2014).

Specific volume (SV) measures extrudate volumetric expansion by adding axial and radial expansions (SPINELLO et al., 2014). The SV ranged between 2.08 and $11.23 \mathrm{~mL} \mathrm{~g}^{-1}$. Data analysis showed a positive linear effect of temperature and negative linear and positive quadratic effect of humidity. High temperatures and low humidity generated products with elevated SV (Figure 1b).

Evaluating the WSI, values ranged from 32.88 to $63.72 \%$. The results were higher than the ones reported by CAMARGO et al. (2008), who assessed extruded biscuits from sour starch and fiber and observed variation from 23.17 to $29.23 \%$. Solubility showed a positive linear effect of temperature and negative linear and positive quadratic effect of moisture. The model was predictive $(\mathrm{P}<0.05)$ and showed a good data fit. According to GOMES et al. (1983), low compression rates and temperature promote less damage to the starch structure, keeping a greater number of hydrophilic groups available to interact with water and decrease WSI. Figure 1c 
Table 2 - Regression coefficients estimated for extrusion parameters of potato flour from 'Ibituaçú' cultivar $\left(\mathrm{y}_{\mathrm{k}}=\beta_{0}+\beta_{1} \mathrm{x}_{1}+\beta_{2} \mathrm{x}_{2}+\beta_{3} \mathrm{x}_{3}+\right.$ $\left.\beta_{12} x_{1} x_{2}+\beta_{13} x_{1} x_{3}+\beta_{23} x_{2} x_{3}\right)$.

\begin{tabular}{|c|c|c|c|c|c|c|c|c|}
\hline & EI & SV & WAI & WSI & $\mathrm{L}^{*}$ & $a^{*}$ & $b^{*}$ & $\mathrm{H}$ \\
\hline Intercept & 3.63 & 4.16 & 6.64 & 42.07 & 55.80 & 6.07 & 17.79 & 10.95 \\
\hline $\mathrm{T}$ & $0.26^{*}$ & $0.93 * *$ & $-0.72 * * *$ & $3.05^{*}$ & $1.76^{* *}$ & $0.24 *$ & $1.58 * * *$ & $-3.47 * *$ \\
\hline M & $-0.35^{* *}$ & $-1.96^{* * *}$ & $-0.94 * * *$ & $-5.52 * *$ & $-2.90 * * *$ & $\mathrm{~ns}$ & $-0.91 * * *$ & $\mathrm{~ns}$ \\
\hline SS & ns & $\mathrm{ns}$ & $\mathrm{ns}$ & ns & $\mathrm{ns}$ & ns & -0.22 & ns \\
\hline T.T & 0.27 & $\mathrm{~ns}$ & $-0.22 *$ & $\mathrm{~ns}$ & ns & $\mathrm{ns}$ & $0.54 * * *$ & $3.01 * *$ \\
\hline M.M & $\mathrm{ns}$ & 0.87 & $-0.29 * *$ & $3.45^{*}$ & $2.20 * *$ & ns & $1.13 * * *$ & $\mathrm{~ns}$ \\
\hline SS.SS & ns & ns & ns & ns & $\mathrm{ns}$ & $\mathrm{ns}$ & $\mathrm{ns}$ & $\mathrm{ns}$ \\
\hline T.M & ns & ns & $0.39 * *$ & ns & ns & $\mathrm{ns}$ & ns & $-3.77 * *$ \\
\hline T.SS & ns & ns & $-0.30^{*}$ & ns & ns & ns & ns & $-2.60 *$ \\
\hline M.SS & $\mathrm{ns}$ & ns & $0.36^{* *}$ & ns & ns & ns & 0.38 & ns \\
\hline $\mathrm{R}^{2}$ & 0,78 & 0,92 & 0,96 & 0,75 & 0,87 & 0,58 & 0,98 & 0,84 \\
\hline
\end{tabular}

$\mathrm{T}=$ temperature (linear), $\mathrm{M}=$ moisture (linear), $\mathrm{SS}=$ screw speed (linear), $\mathrm{T} . \mathrm{T}=$ temperature (quadratic), $\mathrm{M} . \mathrm{M}=$ moisture $(\mathrm{quadratic}), \mathrm{SS} . \mathrm{SS}=$ screw speed (quadratic), EI= expansion index, $\mathrm{SV}=$ specific volume, WAI $=$ water absorption index, $\mathrm{WSI}=$ water solubility index, $\mathrm{L} *=$ luminosity, $\mathrm{b}^{*}=$ (blue to yellow), $\mathrm{a} *=$ (green to red), $\mathrm{H}=$ hardness, $\mathrm{R}^{2}=$ determination coefficient $*, * * \mathrm{e} * * *$ significant at the $5 \%, 1 \% \mathrm{e}$ $0,1 \%$, respectively.

shows low humidity and high temperature conditions generated extrudates with a high WSI. Nevertheless, CARVALHO et al. (2002) found higher values under high humidity for wheat, rice and banana flour mixtures under $100 \mathrm{rpm}$ rotation.

The WAI ranged from 4.02 to $8.97 \mathrm{~g}_{\text {gel }} \mathrm{g}^{-1}$. Regression model best fitted to data with $\mathrm{R}^{2}=0.96$. Results showed negative linear and quadratic effect of temperature and humidity; and besides a positive interaction between temperature and humidity, a negative interaction between temperature and screw speed was seen together with humidity and screw speed interaction. Figures 1d and 1e highlight high temperatures; humidity and screw rotation promote lower WAI. Therefore, to obtain a high index, extrusion parameters should have low humidity $(12 \%)$, temperature (about $100^{\circ} \mathrm{C}$ ) and screw rotation around 190rpm. HASHIMOTO \& GROSSMANN (2003) observed in cassava extrudates a WAI reduction with temperature increase, which varied from 150 to $210^{\circ} \mathrm{C}$, and assigning such phenomenon to possible starch degradation.

Low humidity in combination with high screw speed contributes to degrade starch granules reducing water absorption. Moreover, high moisture values decrease shearing effect, and in line with high temperatures favor gelatinization, and thus release hydroxyl group $\left(\mathrm{OH}^{-}\right)$, which favors hydration (MARZEC \& LEWICKI, 2006). As mentioned by DE PILLI et al. (2011) the lipid content can influence the absorption rate of the extruded products. It is believed that the lubricating effect of lipids within the extruder reduces the friction between the dough and the screw causing the decrease in WAI. Given the above, this effect could have influenced the absorption of water by the extruded seen considerable lipids content of potato flour $(7.4 \%)$.

Extrudate hardness $(\mathrm{H})$ ranged from 7.54 to $29.85 \mathrm{~kg}$. Model was significant and analysis showed a negative linear and positive quadratic effect of temperature and negative interaction between temperature with screw speed and with humidity. As shown in figure 1f, extrudates with lower $\mathrm{H}$ are obtained when products are submitted to average temperature. In contrast, low temperatures increase H level. ALVES \& GROSSMANN (2002) found low $\mathrm{H}$ values in extrudates from yam flour under low humidity and high temperature. Additionally, LUSTOSA et al. (2010) found low $\mathrm{H}$ for cassava flour enriched with extruded casein under low humidity, temperature and protein content. Increase in the extrusion temperature decreases the viscosity of the molten material, favoring the appearance of bubbles, resulting in products with low density and high crispness (DING et al., 2005).

Lightness $\left(\mathrm{L}^{*}\right)$ ranged from 53.89 to 68.72. Temperature and humidity had respectively linear positive and negative quadratic effects. The adopted model is suitable for forecasting of lightness $(\mathrm{P}<0.05)$ with $\mathrm{R}^{2}=0.87$. Lower lightness values were obtained under intermediate humidity levels and low temperatures, while high temperatures and low humidity showed signs of turning brown in extrudates (Figure 1g). Regarding color components, chroma $\mathrm{a}^{*}$

Ciência Rural, v.45, n.12, dez, 2015. 


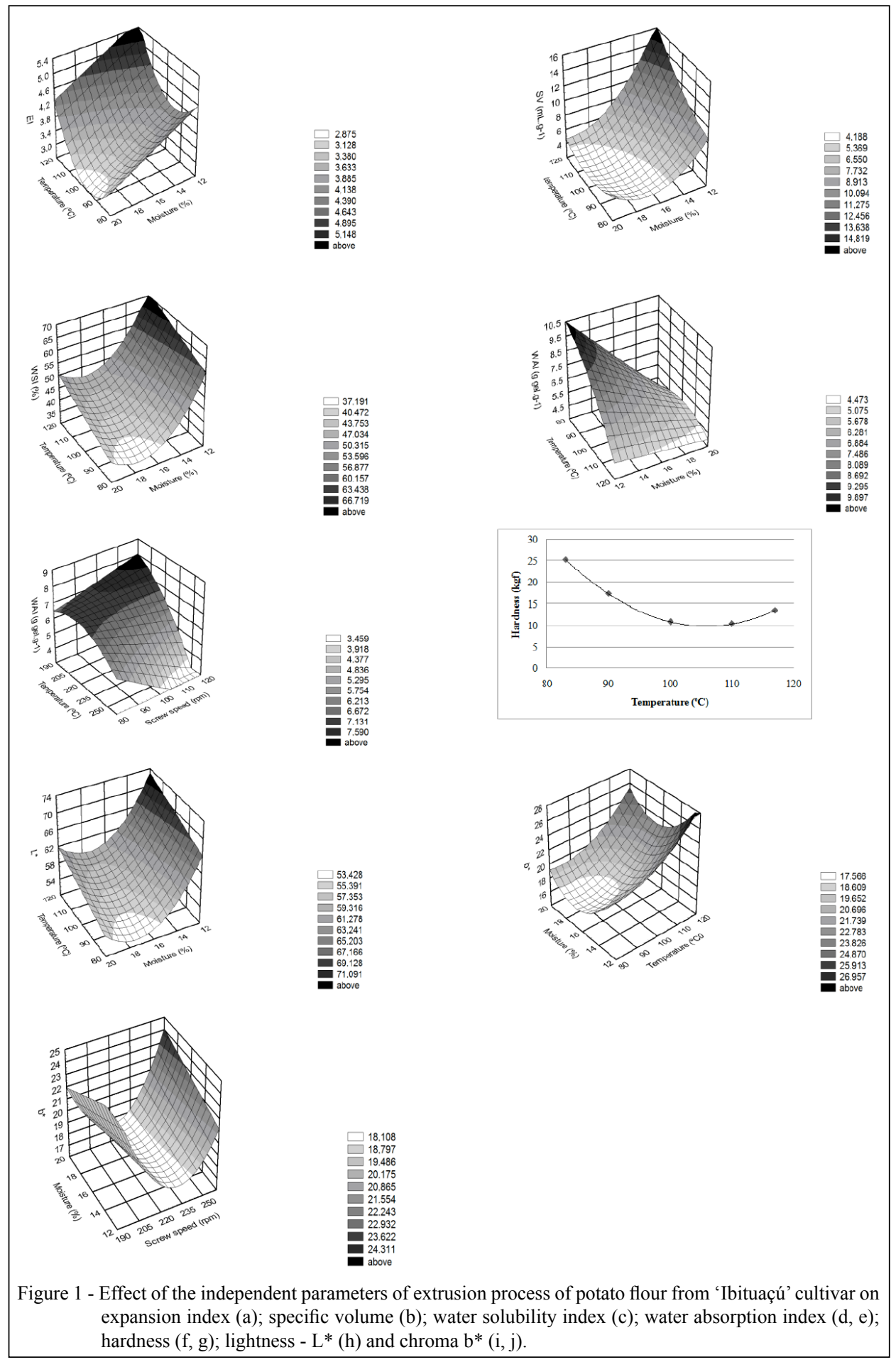

ranged from 5.59 to 6.92 , for which found model was not significant $(\mathrm{P}>0.05)$. Chroma $\mathrm{b}^{*}$ analysis showed a variation between 16.6 and 22.66 , which indicates distinctive presence of the yellow component $(+b)$. Regression coefficients showed positive linear and quadratic effect of temperature, negative linear and positive quadratic effect of humidity, negative linear effect of screw rotation and positive interaction of humidity and screw speed. The model was significant $(\mathrm{P}<0.05)$ with $\mathrm{R}^{2}=0.98$. The lowest values of chroma 
$\mathrm{b}^{*}$ were obtained under high humidity and screw speed but at low temperature (Figures $1 \mathrm{~h}$ and 1i). Color formation during the extrusion process provides important information about thermal treatment. The stability of color is one of the most important quality characteristics for extruded foods since they are usually consumed directly, i.e. they are not used as ingredients in other food products (SOUZA, et al., 2007).

\section{CONCLUSION}

Extrudates with intended technological traits such as high EI, SV and WAI, low hardness and light coloration can be obtained in extrusion process under high temperature, low humidity and intermediate screw speed.

\section{ACKNOWLEDGEMENTS}

The authors want to thank the Conselho Nacional de Desenvolvimento Científico e Tecnológico (CNPq) for research support.

\section{REFERENCES}

ALVES, R.M.L. \& GROSSMANN, M.V.E. Parâmetros de extrusão para produção de snacks de farinha de cará (Dioscoreaalata). Ciência e Tecnologia de Alimentos, v.22, n.1, p.32-38, 2002. Available from: <http://www.scielo.br/pdf/cta/v22n1/a06v22n1. pdf $>$. Accessed: Jun. 20, 2014.

ANDERSON, R.A. et al. Gelatinization of corn grits by extrusioncooking. Cereal Science Today, v.14, n.1, p.4-12, 1969.

ASSOCIATION OF OFFICIAL ANALYTICAL CHEMISTS INTERNATIONAL. AOAC - International. 18.ed. Gaithersburg, 2007. Current Through Revision 2.

CAMARGO, K.F. et al. Produção de biscoitos extrusados de polvilho azedo com fibras: efeito de parâmetros operacionais sobre as propriedades físicas. Ciência e Tecnologia de Alimentos, v.28, n.3, p.586-591, 2008. Available from: <http://www.scielo.br/pdf/ cta/v28n3/a13v28n3.pdf $>$. Accessed: Jul. 11, 2014.

CARVALHO, R.V. et al. Efeito dos parâmetros de extrusão nas propriedades físicas de extrusados $(3 \mathrm{G})$ de misturas de farinhas de trigo, arroz e banana. Ciência e Agrotecnologia, v.26, n.5, p.10061018, 2002.

DE PILLI, T. et al.Study of starch-lipid complexes in model system and real food produced using extrusing cooking technology. Innovative Food Science an Emerging Technologies, v.12, n.4 p.610-616, 2011. Available from: <http://www.sciencedirect.com/ science/article/pii/S146685641100107X\#>. Accessed: Jul. 22, 2014. doi: 10.1016/j.ifset.2011.07.011.

DING, Q. et al.The effect of extrusion conditions on the physicochemical properties and sensory characteristics of rice based expanded snacks. Journal of Food Engineering, v.66, n.3, p.283-289, 2005. Available from: <http://www.sciencedirect.com/
science/article/pii/S0260877404001426>. Accessed: Jul. 25, 2014. doi: 10.1016/j.jfoodeng.2004.03.019.

FAO. International year of the potato 2008. New light on a hidden treasure. Rome: FAO, 2009. Available from: <http://www.fao.org/ docrep/011/i0500e/i0500e00.htm>. Accessed: Jul. 22, 2014.

FAUBION, J.M. \& HOSENEY, R.C. High temperature and short time. Extrusion-cooking of wheat starch and flour. IEffect ofmoisture and flour type on extrudate properties. Cereal Chemistry, v.59, n.6, p.529-533, 1982.Available from: <http:// www.aaccnet.org/cerealchemistry/Contents/NovDec82.asp >. Accessed: Jun. 25, 2014.

FELLOWS, P.J. Tecnologia do processamento de alimentos: princípios e práticas. 2.ed. Porto Alegre: Artmed, 2006. 602p.

FERRARI, A.C. et al. Physical properties of snacks made from cassava leaf flour. Semina: Ciências Agrárias, v.35, n.1, p.317326, 2014. Available from: <http://www.uel.br/revistas/uel/index. php/semagrarias/article/view/14781/pdf_234>. Accessed: Jul. 21, 2014. doi: $10.5433 / 1679-0359.2014 \mathrm{v} 35 \mathrm{n} 1 \mathrm{p} 317$.

GOMEZ, M.H. \& AGUILERA, J.M. Changes in the starch fraction during extrusion-cooking of corn. Journal of Food Science, v.48, n.2, p.378-381, 1983.

HASHIMOTO, J.M.\& GROSSMANN, M.V.E. Effects of extrusion conditions on quality of cassava bran/cassava starch extrudates. International Journal of Food Science and Technology, v.38, n.5, p.511-517, 2003. Available from: <http://onlinelibrary.wiley.com/ doi/10.1046/j.1365-2621.2003.00700.x/epdf>. Accessed: Jun. 22, 2014.

LEONEL, M. et al. Physical characteristic of extruded cassava starch. Scientia Agricola, v.66, n.4, p.486-493, 2009. Available from: $<$ http://www.scielo.br/pdf/sa/v66n4/a09v66n4.pdf $>$. Accessed: Jun. 20, 2014. doi: 10.1590/S0103-90162009000400009.

LEONEL, M.et al. Efeitos de parâmetros de extrusão nas propriedades físicas de produtos expandidos de inhame. Ciência e Tecnologia de Alimentos, v.26, n.2, p.459-464, 2006. Available from: <http://www. scielo.br/pdf/cta/v26n2/30198.pdf>. Accessed: Jun. 17, 2014.

LUSTOSA, B.H.B. et al. Parâmetros de extrusão na produção de snacks de farinha de mandioca enriquecidos com caseína. Semina: Ciências Agrárias, v.31, n.1, p.109-126, 2010. Available from: $<$ http://www.uel.br/revistas/uel/index.php/semagrarias/article/ view/4895/4361>. Accessed: Jun. 17, 2014.

MARZEC, A. \& LEWICKI, P.P. Antiplasticization of cerealbased products by water. Part I: extruded flat bread. Journal of Food Engineering, v.73, n.1, p.1-8, 2006. Available from: <http:// www.sciencedirect.com/science/article/pii/S0260877405000051>. Accessed: Jul. 22, 2014. doi: 10.1016/j.jfoodeng.2004.12.002.

RAMOS, V.J. et al. Avaliação agronômica e qualidade da produção de genótipos de batata nas Regiões Sudoeste e Nordeste do Estado de São Paulo. Horticultura Brasileira, v.27, n.2, p.S2708-S2714, 2009. Available from: <http://www.researchgate. net/publication/266492813>. Accessed: Jul. 15, 2014.

RICKARD, J.E. \& BEHN, K.R. Evaluation of acid and enzyme hydrolytic methods for determination of cassava starch. J Sci Food Agric, v.41, n.4, p.373-379, 1987. Available from: <http://dx.doi. org/10.1002/jsfa.2740410409>. Accessed: Jul. 17, 2014. 
SALATA et al. Extrusion of blends of cassava leaves and cassava flour: physical characteristics of extrudates. Food Science and Technology, v.34, n.3, p.501-506, 2014. Available from: <http:// www.scielo.br/pdf/cta/v34n3/10.pdf $>$. Accessed: Jan. 17, 2015. doi: 10.1590/1678-457X.6337.

SOUZA, L.B. et al. Efeitos dos parâmetros de extrusão nas propriedades físicas de extrusados de misturas de fécula de mandioca e polpa cítrica. Alimentos e Nutrição, v.18, n.1, p.8391, 2007. Available from: <http://serv-bib.fcfar.unesp.br/seer/ index.php/alimentos/article/view/138>. Accessed: Jul. 17, 2014.

SPINELLO, A.M. et al. Cassava and turmeric flour blends as new raw materials to extruded snacks. Ciência e agrotecnologia, v.38, n.1, p.68-75,
2014. Available from: <http://www.scielo.br/pdf/cagro/v38n1/v38n1a08. pdf>. Accessed: Jan. 17, 2015. doi: 10.1590/S1413-70542014000100008.

TAVERNA, L.G. et al. Changes in physical properties of extruded sour cassava starch and quinoa flourblend snacks. Ciência e Tecnologia de Alimentos, v.32, n.4, p.826-834, 2012. Available from: $\quad<$ http://www.scielo.br/pdf/cta/v32n4/aop cta 5629.pdf $>$. Accessed: Jan. 17, 2015.

VERNAZA, M.G. et al. Efeito do teor de farelo de maracujá e da umidade e temperatura de extrusão no desenvolvimento de cereal matinal funcional orgânico. Brazilian Journal of Food Technology, v.12, n.2, p.145-154, 2009. Available from: <http:// dx.doi.org/10.4260/BJFT20097108>. Accessed: Jun. 10, 2014. 